\title{
PENINGKATAN AKTIVITAS DAN HASIL BELAJAR SISWA DALAM PEMBELAJARAN IPS TERPADU DENGAN MODEL COOPERATIVE LEARNING TIPE TWO STAY TWO STRAY DI KELAS VII1 MTSN 11
}

\author{
Sri Hayati \\ MTsN 11 AGAM \\ Email : srihayati1419@gmail.com
}

\begin{abstract}
Abstrak
Tujuan penelitian ini adalah mendeskripsikan peningkatan aktivitas dan Hasil Belajar Siswa Dalam Pembelajaran IPS Dengan Menggunakan Model Cooperative Learning Tipe Two Stay Two Stray di Kelas VII 1 MTsN 11 Agam. Jenis penelitian yang dilakukan adalah penelitian tindakan kelas yang dilaksanakan dalam 2 siklus yang meliputi perencanaan, pelaksanaan, pengamatan dan refleksi. Subjek penelitian adalah siswa Kelas VII 1 MTsN 11 Agam yang berjumlah 32 orang. Aktivitas belajar siswa memperoleh rata-rata kelas $59,90 \%$ pada siklus I. Pada siklus II rata-rata kelas yang diperoleh adalah $82,02 \%$. Hasil belajar siswa memperoleh rata-rata kelas 71,8 pada siklus I. Pada siklus II rata-rata kelas yang diperoleh adalah 81,99. Dengan demikian, dapat disimpulkan bahwa Model Cooperative Learning Tipe Two Stay Two Stray dapat meningkatkan hasil belajar siswa dalam pembelajaan IPS Terpadu di kelas VII 1 MTsN 11 Agam.
\end{abstract}

Kata Kunci: hasil belajar, model cooperative learning tipe two stay two stray

\section{Abstract}

The purpose of this study was to describe the increase in activity and student learning outcomes in social studies learning using the Two Stay Two Stray Cooperative Learning Model in Class VII 1 MTsN 11 Agam. The type of research carried out is classroom action research which is carried out in 2 cycles which includes planning, implementation, observation and reflection. The research subjects were students of Class VII 1 MTsN 11 Agam, totaling 32 people. Student learning activities obtained an average grade of $59.90 \%$ in the first cycle. In the second cycle the average grade obtained was $82.02 \%$. Student learning outcomes obtained a class average of 71.8 in the first cycle. In the second cycle the average grade obtained was 81.99. Thus, it can be concluded that the Two Stay Two Stray Cooperative Learning Model can improve student learning outcomes in Integrated Social Studies learning in class VII 1 MTsN 11 Agam.

Keywords: learning outcomes, cooperative learning model type two stay two stray

\section{PENDAHULUAN}

Pelajaran IPS Terpadu merupakan pelajaran yang sangat penting bagi kehidupan siswa. Karena mata pelajaran IPS mengkaji fakta, konsep maupun generasi yang berkaitan dengan isu sosial yang berkembang di lingkungannya. Guru dalam melaksanakan pembelajaran IPS juga harus berusaha menciptakan 
pembelajaran yang menyenangkan bagi siswa dan menitik beratkan pada keaktifan siswa dalam belajar baik itu pembelajaran secara klasikal maupun berkelompok. Dengan adanya melibatkan siswa secara aktif dalam proses pembelajaran, tentu akan meningkatkan pemahaman siswa terhadap materi yang diajarkan, membuat siswa lebih termotivasi lagi untuk belajar dan akhirnya berimbas kepada peningkatan hasil belajarnya.

Penggunaaan metode klasikal atau ceramah dianggap oleh guru sebagai metode paling mudah untuk mengelola kelas dan bisa mengejar target materi yang harus diselesaikan. Dengan metode ceramah peranan guru sangat dominan, guru sebagai subyek penyampai informasi, guru merupakan pusat perhatian, guru lebih banyak berbicara sedangkan murid hanya mendengarkan atau mencatat hal-hal yang penting. Sehingga berdampak kurang baik kepada hasil belajar siswa pada pembelajaran IPS

Kenyataan yang sama juga terjadi di kelas penulis. Hal ini berdasarkan observasi yang penulis lakukan di kelas VII 1 MTsN 11 Agam, penulis menemukan permasalahan-permasalahan aktivias pelaksanaan proses pembelajaran IPS yang dilaksanakan di kelas seperti: Pertama, dalam melaksanakan pembelajaran IPS di kelas cenderung hanya mengacu pada buku paket saja. Kedua, dalam pelaksanaan pembelajaran di kelas, terlihat guru cenderung menggunakan metode ceramah dan kurang melibatkan siswa secara aktif dalam proses pembelajaan. Ketiga, pada saat pembentukan kelompok belajar, guru kurang memperhatikan keheterogenan (jenis kelamin dan tingkat akademik siswa) dan cenderung membentuk kelompok berdasarkan tempat duduk yang berdekatan. Keempat, guru dalam belajarkan siswa secara berkelompok, jarang sekali melibatkan siswa untuk saling berinteraksi antara kelompok yang satu dengan kelompok yang lain.

Rendahnya aktivitas siswa ini dan kecenderungan pembelajaran hanya menggunakan metode berupa ceramah dan hafalan mengakibat rendahnya hasil belajar siswa. Berdasarkan permasalahan yang peneliti temukan dan penjelasan mengenai Model Cooperative Learnng Tipe Two Stay Two Stray, maka peneliti tertarik melakukan penelitian tindakan kelas dengan judul "Peningkatan aktivitas dan Hasil Belajar Siswa Dalam Pembelajaran IPS Terpadu Dengan Model Cooperative Learning Tipe Two Stay Two Straydi Kelas VII 1 MTsN 11 Agam". tujuan penelitian ini secara umum adalah untuk mendeskripsikan Peningkatan aktivitas dan Hasil Belajar Siswa Dalam Pembelajaran IPS Terpadu Dengan Menggunakan Model Cooperative Learning Tipe Two Stay Two Stray di Kelas VII 1 MTsN 11 Agam.

Menurut Nanang dan Cucu (2009:23) bahwa "Aktifitas belajar merupakan proses aktivitas pembelajaran harus melibatkan seluruh aspek peserta didik, baik jasmani maupun rohani sehingga perubahan perilakunya dapat berubah dengan cepat, tepat, mudah dan benar, baik berkaitan dengan aspek kognitif afektif maupun psikomotor".

Menurut Rusman (2012:123) "Hasil belajar adalah sejumlah pengalaman yang diperoleh siswa yang mencakup ranah kognitif, afektif, psikomotor dan belajar tidak hanya penguasaan konsep teori mata pelajaran saja tapi juga 
penguasaan kebiasaan, persepsi, kesenangan, minat-bakat, penyesuaian sosial, macam-macam keterampilan, cita-cita, keinginan, dan harapan".

Menurut Slavin (dalam Isjoni, 2012:15) "Cooperative Learning adalah suatu model pembelajaran dimana sistem belajar dan bekerja dalam kelompokkelompok kecil yang berjumlah 4-6 orang secara kolaboratif sehingga dapat merangsang siswa lebih bergairah dalam belajar". Sedangkan menurut Jumanta (2014:64) "Cooperative Learning merupakan model pembelajaran dengan menggunakan sistem pengelompokkan/ tim kecil, yaitu antara empat sampai enam orang yang memiliki latar belakang kemampuan akademik, jenis kelamin, ras atau suku yang berbeda".

Pembelajaran IPS dengan menggunakan Model Cooperative Learning Tipe Two Stay Two Stray dapat meningkatkan aktivitas dan hasil belajar siswa pada pembelajaran IPS Terpadu di kelas VII 1 MTsN 11 Agam. Dengan menggunakan Model Cooperative Learning Tipe Two Stay Two Stray ini secara tidak sadar mengajarkan siswa untuk aktif, serta melatih kerjasama dan kekompakkan dalam berdiskusi sehingga pembelajaran menjadi lebih bermakna. Untuk peningkatan proses pembelajaran siswa di sekolah khususnya pelajaran IPS selain menggunakan Model Cooperative Learning Tipe Two Stay Two Stray, banyak lagi jenis model pembelajaran yang dapat digunakan salah satunya model kooperatif tipe Teams Games Tournament (TGT) sejalan dengan pendapat Marcelina, S., Melindawati, S., \& Putera, R. F. (2018) bahwa model kooperatif tipe Teams Games Tournament (TGT) dapat meningkatkan proses pembelajaran anak di sekolah.

\section{METODE}

Jenis penelitian yang dilaksanakan adalah Penelitian Tindakan Kelas (PTK). Penelitian tindakan kelas adalah penelitian yang dilaksanakan didalam kelas. Menurut Uno (2012:41) "Penelitian tindakan kelas adalah penelitian yang dilakukan oleh guru di dalam kelasnya sendiri melalui refleksi diri, dengan tujuan untuk memperbaiki kinerjanya sebagai guru, sehingga proses pembelajaran dapat berjalan dengan baik, dan hasil belajar siswa meningkat".

Populasi penelitian yaitu seluruh siswa kelas VII MTsN 11 Agam sedangkan sampel dalam penelitian ini adalah siswa kelas VII 1 MTsN 11 Agam dengan jumlah siswa 32 orang. Yang terdiri dari 12 orang siswa laki-laki dan 20 orang siswa perempuan.

Menurut Kemmis (dalam Uno, 2012:87) "Proses penelitian tindakan merupakan daur ulang atau siklus yang dimulai dari aspek yang dikembangkan melalui empat komponen, yaitu perencanaan, tindakan, pengamatan, dan refleksi".

Data penelitian ini dikumpulkan dengan tes dan non tes, penelitian ini direncanakan dalam 2 siklus. Pada setiap akhir tindakan dilakukan tes akhir. Instrumen digunakan dalam penelitian ini yaitu 1) lembar non tes berupa lembar observasi untuk menentukan aktivitas dan hasil belajar siswa dari aspek afektif dan psikomotor. 2) lembar tes terdiri dari beberapa soal yang disusun sesuai dengan indikator dan tujuan pembelajaran yang telah ditentukan. 
Data yang diperoleh dalam penelitian ini akan dianalisis dengan menggunakan model analisis data kualitatif dan kuantitatif. Seperti yang diungkapkan Miles dan Huberman (dalam Basrowi, 2008:209) "Analisis data kualitatif mencakup tiga kegiatan yang bersamaan, yaitu 1) reduksi data, 2) penyajian data, 3) penarikan kesimpulan".

\section{HASIL PEMBAHASAN}

Pada bagian ini dipaparkan hasil penelitian dan pembahasan tentang pelaksanaan kegiatan peningkatan hasil belajar siswa dalam pembelajaran IPS Terpadu dengan Model Pembelajaran Cooperative Learning Tipe Two Stay Two Straydi kelas VII 1 MTsN 11 Agam semester I tahun ajaran 2019/2020, dengan jumlah siswa 32 orang. Dalam pelaksanaan tindakan dibagi atas dua siklus, siklus 1 dilaksanakan 2 x pertemuan dan siklus 2 dilaksanakan $2 \times$ pertemuan.

Hasil penelitian pada setiap siklus dapat dideskripsikan sebagai berikut:

\section{Siklus I}

\section{Aktivitas belajar siswa siklus I}

Berdasarkan analisis data pengamatan aktivitas belajar siswa pada siklus I pertemuan I diperoleh rata-rata Visual activities siswa yaitu 62,5\%, Oral Activities yaitu 21,87\%, Writing Activities, yaitu 50\% dan Listening Activities yaitu $56,25 \%$. Rata-rata kelas aktivitas belajar siswa siklus I pertemuan I yaitu $47,66 \%$ dengan kualifikasi kurang. Selanjutnya pada siklus I pertemuan II diperoleh rata-rata Visual activities siswa yaitu 68,75\%, Oral Activities yaitu 40,6\%, Writing Activities, yaitu 62,5\% dan Listening Activities yaitu 68,75\%. Rata-rata kelas aktivitas belajar siswa siklus I pertemuan II yaitu 60,15\% dengan kualifikasi cukup. Namun jika dilihat dari data rekapitulasi aktivitas siswa siklus I secara keseluruhan, menunjukkan rata kelas aktivtas belajar siswa pada siklus I ini adalah 53,90\% dengan kualifikasi kurang.

Hasil yang demikian menunjukkan bahwa aktivitas siswa belum sesuai dengan yang diharapkan. Hal tesebut disebabkan oleh beberapa hal yaitu. Perencanaan dan pelaksananaan pembelajaran IPS dengan menggunakan Model Cooperative Learning Tipe Two Stay Two Strayyang belum maksimal, masih banyak siswa yang belum melaksanakan diskusi kelompok dengan sungguh-sungguh dan sesuai dengan tatacara diskusi kelompok yang telah ditetapkan, dan kurangnya motivasi belajar yang diberikan guru kepada siswa sehingga mengurangi semangat siswa dalam belajar. Untuk itu upaya yang dilakukan yaitu mengatasi kekurangan dan memaksimalkan pembuatan perencanaan dan pelaksananaan pembelajaran IPS menggunakan Model Cooperative Learning Tipe Two Stay Two Stray

Aktivitas belajar siswa ini diamati oleh observer saat proses pembelajaran berlansung melaui lembat pengamatan yang telah disediakan. Aktivitas belajar siswa adalah semua kegiatan yang dilakukan oleh siswa selama mengikuti proses pembelajaran, baik secara fisik maupun mental. Jenis Aktivitas yang peneliti teliti didasarkan pada pendapat Paul B. Diedric (Sardiman, 2010: 101) yang menyatakan bahwa jenis aktivitas dapat di bagi menjadi 8 yaitu :

1) Visual activities, yang termasuk di dalamnya misalnya membaca, memperhatikan gambar demonstrasi, percobaan, pekerjaan orang lain. 2) Oral Activities, seperti menyatakan merumuskan, bertanya, memberi saran, 
berpendapat, diskusi, interupsi. 3) Listening Activities, sebagai contoh mendengarkan: uraian, percakapan, diskusi, musik, pidato. 4) Writing Activities, seperti misalnya menulis cerita, karangan, laporan, menyalin. 5) Drawing Activities, menggambar, membuat grafik, peta, diagram. 6) Motor Activities, yang termasuk di dalamnya antara lain: melakukan percobaan, membuat konstruksi, model, mereparasi, berkebun, beternak. 7) Mental Activities, sebagai contoh misalnya: menanggapi, mengingat, memecahkan soal, menganalisis, mengambil keputusan. 8) Emotional Activities, seperti misalnya, merasa bosan, gugup, melamun, berani, tenang.

Namun diantara 8 jenis aktivitas tersebut, empat aktivitas saja yang peneliti teliti. Hal ini disesuaikan dengan materi dan model pelajaran yang peneliti pakai dalam proses pembelajaran. Keempat aktivitas yang peneliti teliti tersebut yaitu 1) Visual activities, 2) Oral Activities, 3) Writing Activities, 4) Listening Activities.

\section{Hasil Belajar Siklus I}

Hasil dari pelaksanakan pembelajaran IPS dengan menggunakan Model Cooperative Learning Tipe Two Stay Two Stray adalah hasih belajar siswa. Menuru Uno (2011:213) "hasil belajar adalah perubahan perilaku yang relatif menetap dalam diri seseorang sebagai akibat dari interaksi seseorang dengan lingkungannya". Hasil belajar ini menjadi tolak ukur keberhasilakan pembelajaran pembelajaran yang telah dilaksanakan. Hasil belajar ini terdiri dari tiga ranah yaitu ranah kognitif, ranah afektif dan ranah psikomotor.

Ungkapan di atas sesuai dengan yang dinyatakan Bloom (dalam Sudjana 2009:22) menyatakan bahwa hasil belajar terdiri tiga ranah yaitu : "1) Ranah kognitif, adalah kemampuan yang berhubungan dengan pengetahuan, pemahaman, aplikasi, analisis, sintesis, dan evaluasi, 2) ranah afektif, adalah kemampuan yang berhubungan dengan sikap, reaksi, dan penilaian, 3) ranah psikomotorik mencakup tujuan yang berkaitan dengan keterampilan dan kemampuan bertindak".

Berdasarkan analisis data pengamatan hasil belajar siswa pada siklus I pertemuan I diperoleh rata-rata nilai koginitif siswa yaitu 70, afektif yaitu 72,99 dan psikomotor yaitu 69,27. Rata-rata kelas hasil belajar siswa siklus I pertemuan I yaitu 70,83 dengan persentase ketuntasan $56,3 \%$. Selanjutnya pada siklus I pertemuan II diperoleh rata-rata nilai koginitif siswa yaitu 72,25 , afektif yaitu 73,66 dan psikomotor yaitu 72,3. Rata-rata kelas hasil belajar siswa siklus I pertemuan II yaitu 72,77 dengan persentase ketuntasan 56,3. Namun jika dilihat dari data rekapitulasi siklus I secara keseluruhan, menunjukkan rata kelas hasil belajar siswa pada siklus I ini adalah 71,8 dengan persentase ketuntasan 56,3\%. Hal ini menandakan ketuntasan hasil belajar siswa belum tercapai sesuai dengan yang diharapkan yaitu lebih dari $75 \%$

Belum sesuainya hasil belajar tersebut dengan kriteria yang diinginkan disebabkan oleh beberapa hal yaitu (1) pelaksananaan pembelajaran IPS Terpadu dengan menggunakan Model Cooperative Learning Tipe Two Stay Two Strayyang belum maksimal, (2) masih banyak siswa yang belum aktif dalam pembelajaran,dan masih kurang memperhatikan guru dalam menyampaikan materi pelajaran, (3) masih banyak siswa yang belum melaksanakan diskusi kelompok dengan sungguh-sungguh dan sesuai dengan tatacara diskusi 
kelompok yang telah ditetapkan (4) kurangnya motivasi belajar yang diberikan guru kepada siswa sehingga mengurangi semangat siswa dalam belajar.

Mengenal hal di atas, Mulyasa (2011:36) menyataan bahwa "guru harus berpacu dalam pembelajaran dengan memberikan kemudahan belajar bagi seluruh peserta didik agar dapat mengembangkan potensinya secara optimal. Dalam hal ini guru harus kreatif, profesional dan mengenangkan"

Berdasarkan paparan data hasil pengamatan hasil belajar siswa pada siklus I, maka direncanakan untuk melakukan perbaikan pada pembelajaran berikutnya yaitu pada siklus II. Perbaikan tindakan yang dilakukan pada siklus II diantaranya (1) mengupayakan keterlibatan siswa dalam pembelajaran agar siswa aktif dalam pembelajaran (2) memberikan motivasi kepada siswa agar siswa lebih serius dan giat dalam belajar, (3) lebih mendekatkan materi pembelajaran dengan kehidupan siswa (4) lebih mengarahkan dan membimbing siswa dalam diskusi kelompok.

\section{Siklus II}

\section{Aktivitas belajar siswa siklus II}

Aktivitas belajar siswa adalah semua kegiatan yang dilakukan oleh siswa selama mengikuti proses pembelajaran, baik secara fisik maupun mental. Ungkapan tersebut sesuai dengan yang dinyatakan oleh Nanang dan Cucu (2009:23) bahwa "Aktifitas belajar merupakan proses aktivitas pembelajaran harus melibatkan seluruh aspek peserta didik, baik jasmani maupun rohani sehingga perubahan perilakunya dapat berubah dengan cepat, tepat, mudah dan benar, baik berkaitan dengan aspek kognitif afektif maupun psikomotor"

Sama halnya dengan siklus I, pada siklus II ini juga ada empat aktivitas yang peneliti teliti. Keempat aktivitas yang peneliti teliti tersebut yaitu 1) Visual activities, 2) Oral Activities, 3) Writing Activities, 4) Listening Activities. Berdasarkan analisis data pengamatan aktivtas belajar siswa pada siklus II pertemuan I diperoleh rata-rata Visual activities siswa yaitu $81,25 \%$, Oral Activities yaitu 65,6\%, Writing Activities, yaitu 75\% dan Listening Activities yaitu $81,25 \%$. Rata-rata kelas aktivitas belajar siswa siklus II pertemuan I yaitu $75,78 \%$ dengan kualifikasi cukup.

Selanjutnya pada siklus II pertemuan II diperoleh rata-rata Visual activities siswa yaitu 93,75\%, Oral Activities yaitu 81,25\%, Writing Activities, yaitu 90,6\% dan Listening Activities yaitu $87,5 \%$. Rata-rata kelas aktivitas belajar siswa siklus II pertemuan II yaitu $88,27 \%$ dengan kualifikasi sangat baik. Namun jika dilihat dari data rekapitulasi aktivitas siswa siklus I secara keseluruhan, menunjukkan rata kelas aktivitas belajar siswa pada siklus II ini adalah $82,02 \%$ dengan kualifikasi baik.

Berdasarkan pemaparan data yang disajikan di atas, dapat disimpulkan bahwa aktivitas belajar siswa pada pembelajaran IPS dengan menggunakan Model Cooperative Learning Tipe Two Stay Two Straydi kelas VII 1 MTsN 11 Agam telah sesuai dengan hasil yang diharapkan dan juga telah meningkat jika dibandingkan dengan aktivitas siswa pada siklus I. 


\section{Hasil Belajar Siswa Siklus II}

Hasil belajar ini menjadi tolak ukur keberhasilakan pembelajaran pembelajaran yang telah dilaksanakan. Hasil belajar ini terdiri dari tiga ranah yaitu ranah kognitif, ranah afektif dan ranah psikomotor. Ungkapan ini sesuai dengan yang dinyatakan Bloom (dalam Sudjana 2009:22) menyatakan bahwa hasil belajar terdiri tiga ranah yaitu : "1) Ranah kognitif, adalah kemampuan yang berhubungan dengan pengetahuan, pemahaman, aplikasi, analisis, sintesis, dan evaluasi, 2) ranah afektif, adalah kemampuan yang berhubungan dengan sikap, reaksi, dan penilaian, 3) ranah psikomotorik mencakup tujuan yang berkaitan dengan keterampilan dan kemampuan bertindak".

Berdasarkan analisis data pengamatan hasil belajar siswa pada siklus II pertemuan I diperoleh rata-rata nilai koginitif siswa yaitu 78,25, afektif yaitu 81,46 dan psikomotor yaitu 78,63. Rata-rata kelas hasil belajar siswa siklus II pertemuan I yaitu 79,45 dengan persentase ketuntasan $68,75 \%$. Selanjutnya pada siklus II pertemuan II diperoleh rata-rata nilai koginitif siswa yaitu 84,25, afektif yaitu 85,48 dan psikomotor yaitu 83,83 . Rata-rata kelas hasil belajar siswa siklus II pertemuan II yaitu 84,53 dengan persentase ketuntasan $100 \%$. Namun jika dilihat dari data rekapitulasi siklus II secara keseluruhan, menunjukkan rata kelas hasil belajar siswa pada siklus II ini adalah 81,99 dengan persentase ketuntasan $100 \%$. Hal ini menandakan upaya perbaikan yang dilakukan pada siklus II telah berhasil

Berdasarkan pemaparan data yang disajikan di atas, dapat disimpulkan bahwa hasil belajar siswa pada pembelajaran IPS Terpadu dengan Model Cooperative Learning Tipe Two Stay Two Straydi kelas VII 1 MTsN 11 Agam telah tercapai dengan kriterian yang telah ditentukan yaitu tingkat ketuntasan siswa sudah lebih dari $75 \%$. Tingkat ketuntasan yang diharapkan ini berdasarkan pendapat Kunandar (2011:149) yang menyatakan "Kriteria ideal ketuntasan untuk masing-masing Kompetensi Dasar adalah 75\%". Hal ini berarti penelitian berhenti pada siklus II dan tidak dilanjutkan pada siklus berikutnya.

Berdasarkan data hasil pengamatan yang telah peneliti bahas di atas yaitu aspek perencanaan, pengamatan aspek guru dan siswa dalam pembelajaran IPS Terpadu dengan Model Cooperative Learning Tipe Two Stay Two Stray, serta aktivitas dan hasil belajar IPS yang meliputi hasil belajar kognitif, afektif dan psikomotor terlihat bahwa terdapat peningkatan pada tiap pertemuannya.

Berdasarkan analisis penelitian pada siklus II, penerapan Model Cooperative Learning Tipe Two Stay Two Straytelah terlaksana sesuai dengan yang diharapkan. Berdasarkan hasil yang diperoleh pada siklus II, maka pelaksanaan pada siklus II telah terlaksana dengan baik dan peneliti telah berhasil menerapkan Model Cooperative Learning Tipe Two Stay Two Straypada pembelajaran IPS Terpadu di kelas VII 1 MTsN 11 Agam dan tidak dilanjutkan dengan siklus berikutnya. 


\section{KESIMPULAN}

Aktivitas belajar siswa dalam pembelajaran IPS Terpadu dengan menggunakan Model Cooperative Learning Tipe Two Stay Two Stray pada pembelajaran IPS Terpadu di kelas VII 1 MTsN 11 Agam memperoleh rata-rata kelas 59,90 \% pada siklus I. Pada siklus II rata-rata kelas yang diperoleh adalah 82,02\%. Dengan demikian, dapat disimpulkan bahwa Model Cooperative Learning Tipe Two Stay Two Stray dapat meningkatkan aktivitas belajar siswa dalam pembelajaan IPS di kelas VII 1 MTsN 11 Agam

Hasil belajar siswa dalam pembelajaran IPS Terpadu dengan menggunakan Model Cooperative Learning Tipe Two Stay Two Stray pada pembelajaran IPS di kelas VII 1 MTsN 11 Agam memperoleh rata-rata kelas 71,8 pada siklus I. Pada siklus II rata-rata kelas yang diperoleh adalah 81,99. Dengan demikian, dapat disimpulkan bahwa Model Cooperative Learning Tipe Two Stay Two Stray dapat meningkatkan hasil belajar siswa dalam pembelajaan IPS Terpadu di kelas VII 1 MTsN 11 Agam.

\section{DAFTAR PUSTAKA}

Basrowi. 2008. Memahami Penelitian Kualitatif. Jakarta: PT Rineka Cipta

Hanafiah, Nanang. (2009). Konsep Strategi Pembelajaran. Bandung: Refika Utama

Isjoni. 2010. Cooperative Learning: Efektifitas Pembelajaran Kelompok. Bandung: Alfabeta.

Jumanta, Hamyama. 2014. Model dan Metode Pembelajaran Kreatif dan Berkarakter. Bogor: Ghalia Indonesia

Marcelina, S., Melindawati, S., \& Putera, R. F. (2018). Peningkatan Proses Pembelajaran IPS Menggunakan Model Kooperatif Tipe Teams Games Tournament (TGT) di Kelas IV SD Negeri 05 Alang Rambah Kabupaten Pesisir Selatan. Jurnal Inovasi Pendidikan dan Pembelajaran Sekolah Dasar, 2(2), 30-51.

Mulyasa. 2011. Manajemen Berbasis Sekolah, Konsep, strategi dan Implementasi. Bandung : PT Remaja Rosdakarya

Rusman. 2012. Belajar dan Pembelajaran Berbasis Komputer. Bandung: Alfabeta.

Sardiman. 2010. Interaksi dan Motivasi Belajar Mengajar. Jakarta : Rajawali Press

Sudjana, Nana. 2009. Penilaian Hasil Proses Belajar mengajar. Bandung : PT. Remaja Rosdakarya.

Uno, Hamzah B.. 2011. Model Pembelajaran: Menciptakan Proses Belajar Mengajar. Jakarta : Bumi 